УДК $338.45(5)$

ББК 65.9(4/8)

СРАВНИТЕЛЬНЫЙ АНАЛИЗ РЕЗУЛЬТАТОВ МОДЕРНИЗАЦИИ КРУПНЕЙШИХ ЭКОНОМИК АЗИАТСКИХ СТРАН

\author{
ЧЖАН БИНЬ \\ munckz222@126.com \\ аспирант кафедры инновационного менеджмента \\ Белорусский государственный университет \\ Минск, Республика Беларусь
}

В статье представлен сравнительный анализ модернизации промышленного комплекса Китая, Сингапура, Южной Кореи и Японии за последние несколько десятилетий. При этом особое внимание сосредоточено на факторах, определяющих эффрективность модернизачии промышленного комплекса исследуемых стран, что позволило установить их общие тенденщии. На основе изучения динамики темпов роста производительности труда и оплаты труда в Китае делается вывод о перспективности проводимой политики модернизачии промышиенного комплекса страны и применении новых механизмов повышения ее эффективности.

Ключевые слова: промышленная политика, промышленный комплекс, модернизация, технологический уклад, производительность труда, ВВП.

\title{
COMPARATIVE ANALYSIS OF THE RESULTS OF MODERNIZATION OF THE LARGEST ECONOMIES OF ASIAN COUNTRIES
}

\author{
CHZHAN BIN' \\ Postgraduate student of the department of innovative management \\ Belarusian State University \\ Minsk, Republic of Belarus
}

The article introduces the comparative analysis of modern industrial compounds in China, Singapore, South Korea and Japan in the past decades. In this particular focus on the effects of efficiency on the general trend of industrial structure upgrading in the country, install them. Dynamics research based on the growth rate of labor productivity and labor remuneration policy conclusion powerful vitality in China and application of the industrialization of the modern state mechanisms, improve its efficiency.

Key words: Industrial policy, industrial cluster, upgrade, technical structure, labor productivity, gross domestic product (GDP).

\section{ВВЕДЕНИЕ}

К сожалению, в последние десятилетия в экономической науке восторжествовала точка зрения о том, что услуги и сервисная экономика - это основные драйверы социально-экономического развития. Однако данные представления в духе «концепции постиндустриального общества», возвеличивающие значимость услуг и тем самым как бы отодвигающие на задний план индустриально-промышленный комплекс и другие традиционные сферы деятельности реального сектора экономики, являются не просто ошибочными, но опасными. Достаточно осмотреться вокруг себя, чтобы понять: все, что 
окружает современного человека - продукты питания, одежда, мебель, жилища, транспортные средства, техника на работе и в быту и т. д., произведено на промышленных предприятиях. Более того, оказание услуг немыслимо без продукции промышленных предприятий - компьютеров и прочей оргтехники, средств связи, косметики и т. п. Поэтому именно промышленность, индустриально-промышленный комплекс является подлинным локомотивом технико-технологического прогресса и социально-экономического развития любой современной державы [1].

Не секрет, что мировой кризис наиболее сильно ударил по тем странам, которые, сделав основную ставку на сферу услуг, вывели свои промышленные активы за рубеж. Сегодня США и страны ЕС, исправляя данный просчет в рамках политики новой индустриализации, вынуждены возвращать «домой» свои промышленные предприятия, «сбежавшие» в Индию, Китай, Южную Корею, Сингапур и т. д. в поисках дешевой рабочей силы. Не случайно стратегия «Industry 4.0» определяет нынешний вектор дальнейшего развития и модернизации национальной экономики большинства технологически развитых и успешно догоняющих их держав [2].

Сегодня Республика Беларусь, также, как и другие страны постсоветского пространства, стремится найти и реализовать наиболее эффективную модель экономического развития, осуществить экономическую модернизацию своей хозяйственной системы [3]. В связи с этим анализ и изучение возможности адаптации лучшего зарубежного опыта, в особенности относящегося к моделям модернизации промышленного комплекса, остается весьма важной и актуальной для белорусской экономики задачей. На наш взгляд, ее решение может быть облегчено при учете результатов предпринятого в данной статье исследования успешной модернизации (инновационного обновления) индустриально-промышленного комплекса четырех достаточно разных по многим своим социально-экономическим параметрам азиатских государств (Сингапур, Япония, Южная Корея и Китай), именуемых в научной литературе «новыми индустриальными странами».

\section{РЕЗУЛЬТАТЫ И ИХ ОБСУЖДЕНИЕ}

Анализ различных аспектов индустриально-промышленной политики в азиатских странах, и прежде всего в демонстрирующем грандиозный технико-технологический прогресс Китае, представляет несомненный интерес. Осуществляя его, мы исходили из фундаментального положения о том, что основным назначением технико-технологического прогресса и его достижений, в конечном счете, является облегчение труда человека, экономия его рабочего времени. По словам крупнейшего экономиста-теоретика К. Маркс, «экономия времени остается первым экономическим законом на основе коллективного производства» [4, с. 117].

Иными словами, широко известный из советской марксистско-ленинской политэкономии тезис о том, что «производительность труда, это, в последнем счете, самое важное, самое главное для победы нового общественного строя» [5, с. 21] сегодня становится актуальнее день ото дня. Неслучайно в современном Китае повышению производительности труда уделяется первостепенное внимание. В своем докладе на XIX съезде Коммунистической партии Китая в октябре 2017 г. китайский лидер Си Цзиньпин в качестве ключевой задачи по превращению Поднебесной в «великую державу современного социализма» выделил необходимость «обеспечить синхронный рост доходов населения и экономического развития, а также соразмерное увеличение оплаты труда с повышением производительности труда» [6]. 
Как известно, в разных странах принята разная периодизация (выделение этапов) технико-технологического прогресса. В США и Европейском союзе в качестве таких этапов сегодня выделяют первую-четвертую индустриальные (промышленные) революции, в странах Евразийского экономического союза (ЕАЭС) - I-VI технологические уклады (т. у.) [1; 2]. В Китае используется иная, более сложная система классификации, включающая первую индустриализацию 1953-1965 гг., модернизацию экономики 19801995 гг. после так называемой инновационной паузы 1966-1976 гг., вторую индустриализацию 1996-2010 гг., а также современный период, именуемый «этапом построения экономики знаний» [2].

Поскольку данное исследование выполнялось в рамках научно-исследовательского проекта «Модернизация (инновационное обновление) промышленного комплекса Беларуси в условиях евразийской интеграции» (задание ГПНИ «Экономика и гуманитарное развитие белорусского общества» (2016-2018 гг.)) технико-технологический прогресс в «новых индустриальных странах» и его влияние на производительность труда изучены с позиций выделения т.у. согласно принятой в Беларуси классификации. При осуществлении расчетов мы учитывали годовые показатели ВВП, а также среднегодовые численности работающих в соответствующих странах. Кроме того, мы учли, что формирование IV-VI-го т. у. в Китае, Японии, Южной Корее и Сингапуре пришлось на разные временные периоды, что соответствующим образом отражено в таблице 1.

Таблица 1 - Показатели роста производительности труда Китая, Сингапура, Южной Кореи и Японии за 1960-2016 гг.

\begin{tabular}{|c|c|c|c|c|c|c|c|c|}
\hline \multirow{3}{*}{ Страна } & \multicolumn{2}{|c|}{ IV-й т.у } & \multicolumn{3}{|c|}{ V-й т.у. } & \multicolumn{3}{|c|}{ VI-й т.у. } \\
\hline & \multirow{2}{*}{ 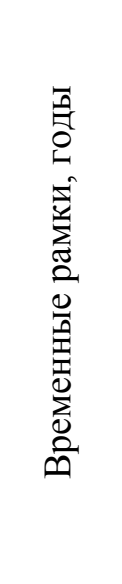 } & \multirow{2}{*}{ 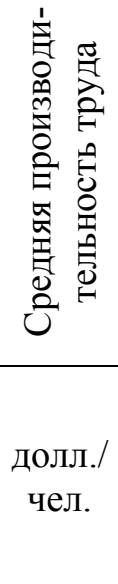 } & \multirow{2}{*}{ 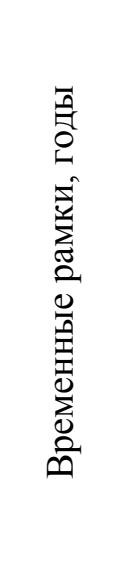 } & \multicolumn{2}{|c|}{ 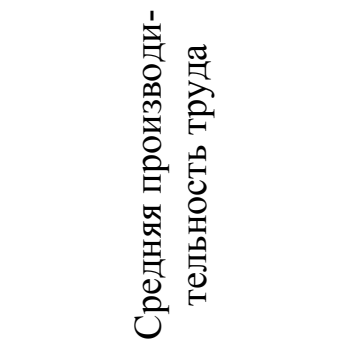 } & \multirow{2}{*}{ 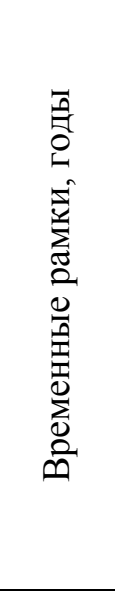 } & \multicolumn{2}{|c|}{ 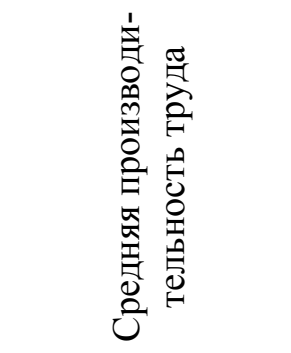 } \\
\hline & & & & $\begin{array}{c}\text { долл./ } \\
\text { чел. }\end{array}$ & $\begin{array}{c}\text { по сравне- } \\
\text { нию с IV-м } \\
\text { т.у., разы }\end{array}$ & & $\begin{array}{c}\text { долл./ } \\
\text { чел. }\end{array}$ & $\begin{array}{c}\text { по срав- } \\
\text { нению с } \\
\text { V-м } \\
\text { т.у., } \\
\text { разы }\end{array}$ \\
\hline Япония & $\begin{array}{c}1940- \\
1960\end{array}$ & 8,21 & $\begin{array}{c}1961- \\
1990\end{array}$ & 49,16 & 5,98 & $\begin{array}{c}1990- \\
2016\end{array}$ & 246,31 & 5,1 \\
\hline Южная Корея & $\begin{array}{c}1950- \\
1973\end{array}$ & 0,92 & $\begin{array}{c}1974- \\
1994\end{array}$ & 6,07 & 6,59 & $\begin{array}{c}1995- \\
2016\end{array}$ & 30,33 & 4,99 \\
\hline Сингапур & $\begin{array}{c}1950- \\
1973\end{array}$ & 0,92 & $\begin{array}{c}1974- \\
1994\end{array}$ & 11,61 & 12,61 & $\begin{array}{l}1995- \\
2016\end{array}$ & 55,94 & 4,81 \\
\hline Китай & $\begin{array}{c}1960- \\
1980\end{array}$ & 3,30 & $\begin{array}{c}1981- \\
2000\end{array}$ & 8,66 & 2,62 & $\begin{array}{c}2001- \\
2016\end{array}$ & 72,99 & 8,42 \\
\hline
\end{tabular}

Источник: разработка автора на основе [10].

Анализ представленной в таблице 1 информации позволяет сделать ряд принципиальных выводов. 
Во-первых, эта информация наглядно подтверждает приведенный выше тезис о повышении производительности труда как основной цели технико-технологического прогресса и его достижений.

Во-вторых, из данных таблицы 1 видно, что разные страны проходили одни и те же этапы технико-технологического прогресса в разное время, то есть он протекает в разных государствах с разной скоростью. Так, Япония, Южная Корея и Сингапур традиционно опережали Китай в формировании очередных ТУ. Однако видно, что скорость роста производительности труда в этих странах (особенно в Сингапуре) уменьшается, а в Китае, наоборот, быстро увеличивается, благодаря чему наша страна стала лидером не только по размерам своей экономики, но уже и во многих областях науки, техники, технологий и инновационной деятельности.

В-третьих, представленная в таблице 1 информация дает возможность по-новому, под иным углом зрения взглянуть на сущность ТУ (и, соответственно, промышленных революций), которые традиционно анализируются достаточно поверхностно - с точки зрения смены характерных для них видов используемой техники, технологии и энергии (эпоха пара, эпоха электричества, эпоха атома и т. д.). Так, например, сегодня уже превратилась в своеобразное клише-шаблон характеристика VI-го ТУ как современного периода эволюции техники и технологий, связанного с массированным внедрение нано-, био-, инфо- и телекоммуникационных и других высоких технологий.

Мы же в отличие от традиционного подхода обращаем первостепенное внимание на политико-экономическую сущность процесса смены технологических укладов, связанной с кратным ростом производительности труда при переходе от одного ТУ к другому. Иными словами, смена технологических укладов сопровождается такими изменениями в технике, технологиях, способах организации производства и управления им, которые обеспечивают кратный рост производительности труда, При этом важно понимать, что человечество интересует не техника сама по себе, а обеспечиваемая ею экономия труда, а значит, ускоряющая развитие общества максимизация его свободного от рутинной работы времени, когда человек может заниматься саморазвитием за счет занятий наукой, искусством, спортом, культурой и т. д.

Данный взгляд на технико-технологический прогресс позволил нам дать новое, учитывающее основное предназначение технико-технологического прогресса определение модернизации экономической системы как процесса кратного роста в ней производительности труда за счет масштабного использования обеспечивающих данное повьшение технико-технологических и организационно-управленческих факторов, относящихся к высшим технологическим укладам.

Вместе с этим остается открытым весьма важный вопрос - за счет чего, каким образом обеспечивается, стимулируется смена технологических укладов, внедрение свойственных им видов техники и технологий, а значит, вызываемое этими процессами кратное повышение производительности труда? (см. таблицу 1)

Согласно данным таблицы 1 , наибольший скачек всех исследуемых показателей Китая был в период 6-ого технологического уклада (2001-2016 гг.), когда ВВП увеличился в 10 раз по сравнению с 1981-2000 гг. и в 54 раза по сравнению с 4-ым технологическим укладом (1960-1980 гг.). При этом наибольший среднегодовой рост производительности труда был зафиксирован в 1960-2016 гг. - в 22 раза. Основой проводимой промышленной политики Китая была первоначальная модернизация крупных экспортоориентированных национальных компаний и одновременное развитие логистической инфраструктуры (портов, торговых площадок, специальных торговых и экономических зон и т. д.), обслуживающей внешнюю торговлю. Достигнув успехов в данном 
процессе, Китай на сегодняшний день стал проводить политику наукоемкого экспорта с целью удержания лидирующих позиций на международных рынках.

Рассматривая опыт Японии, можем отметить, что она имеет отличную от других стран социальную структуру, характеризующуюся дуализмом современной промышленности, а сама экономическая система представлена в виде модели: «рынок - группа предприятий - отдельные предприятия». Успех модернизации промышленного комплекса Японии, в отличие от Китая, был заметен уже в период 5-ого технологического уклада.

Так, максимальные показатели роста ВВП (8 раз) и производительности труда (6 раз) Японии были зафиксированы в период 5-ого технологического уклада (с 1961 по 1990 гг.) по сравнению с показателями 4-ого технологического уклада. Власти Японии проводили классическую экпансионскую промышленную политику, которая была развернута в 1940-50-х гг. На современном этапе наблюдается смещение вектора промышленной политики Японии в сторону перехода наукоемких технологий, где производство, информативность и знания признаются залогом устойчивого экономического роста.

Модернизация промышленного комплекса Южной Кореи, как и других азиатских стран, осуществлялась в несколько этапов - от импортозамещающей к эпортоориентированной.

Показатели динамики ВВП, численности работающих и производительности труда Южной Кореи за 1950-2016 гг. показывают, что наиболее перспективный рост был зафиксирован в 1995-2016 гг. при достаточно равномерном росте трудовых ресурсов. На всех этапах модернизации промышленного комплекса значимую роль играло государственное стратегическое планирование и аккумуляция финансовых средств Центрального банка и Министерства финансов.

Сингапур начал реализовать политику модернизации промышленного комплекса в начале 1950 г., что позволило уже в период 5-ого технологического уклада увеличить объем ВВП в 13,6 раза, а производительность труда в 12,6 раз (см. таблицу 2).

Таблица 2 - Соотношение темпа роста производительности труда и его оплаты Китая, Сингапура, Южной Кореи и Японии

\begin{tabular}{|c|c|c|c|}
\hline \multirow{2}{*}{ Страна } & \multicolumn{3}{|c|}{ Соотношение темпов роста ПТ и оплаты труда, \% } \\
\hline & IV-й ТУ & V-й ТУ & VI-й ТУ \\
\hline Япония & 98,4 & 107,3 & 112,3 \\
\hline Южная Корея & 96,2 & 106,0 & 110,2 \\
\hline Сингапур & 95,6 & 105,7 & 108,1 \\
\hline Китай & 91,2 & 103,2 & 120,5 \\
\hline
\end{tabular}

Источник: разработка автора на основе [10].

Таким образом, на протяжении тридцати-сорока лет рассматриваемые страны демонстрировали миру рекордные темпы роста ВВП, что позволило получить им название «азиатские тигры». В период с 1985 г. по 1992 г. в период «промышленного бума» и восточноазиатской модернизации, среднегодовые показатели прироста экспорта исследуемых азиатских стран в развитые страны составляли $14,7 \%$. 


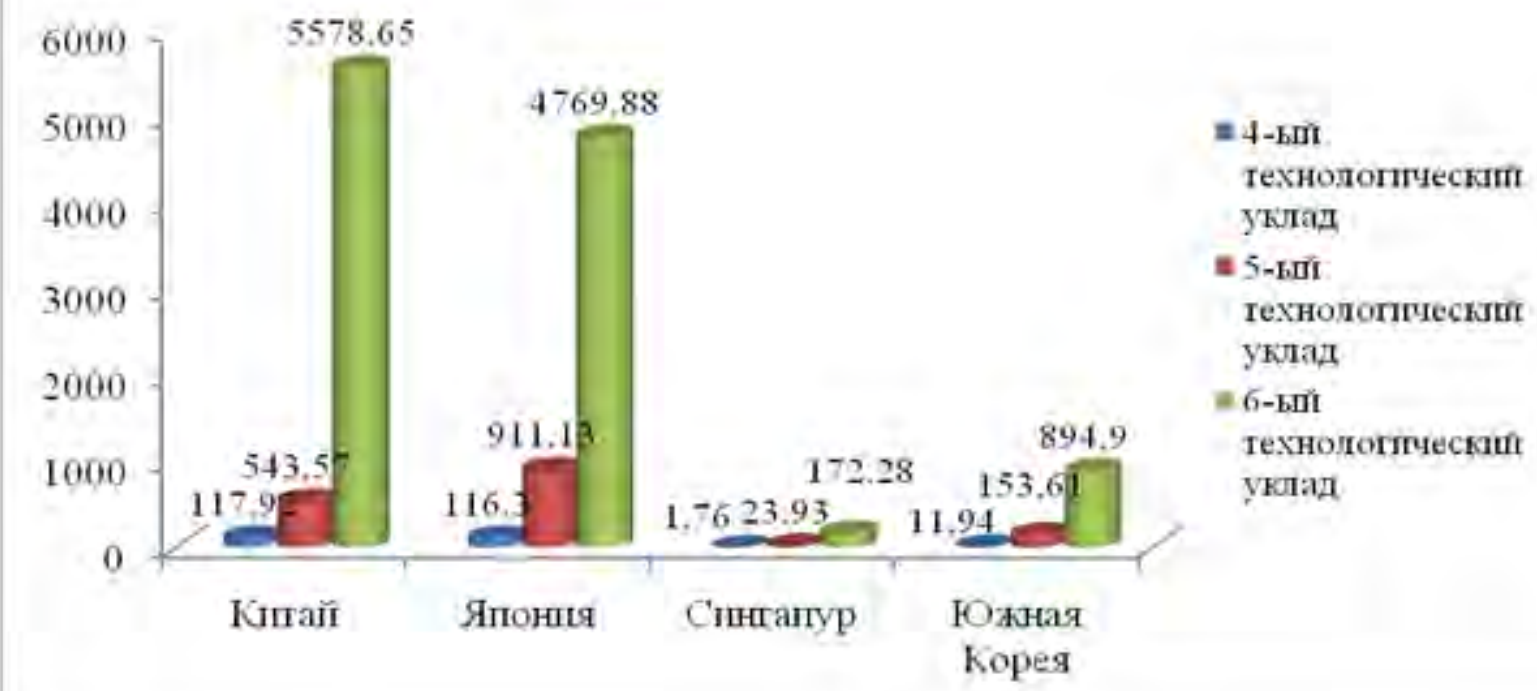

Рисунок 1 - Динамика среднегодовых показателей ВВП азиатских стран по технологическим укладам, млрд долл. США

Источник: разработка автора на основе [10]

Согласно данным рисунка 1, наглядно видно, что наибольшие объемы ВВП азиатских стран были в период 6-ого технологического. При этом график доказывает бум экономического роста Японии уже в период 5-ого технологического уклада (19611990 гг.). Это обстоятельство объясняет более ранним периодом проведения модернизации промышленного комплекса Японии. Плюс ко всему среднегодовые темпы роста работающего населения (экономически занятого населения) в Японии в 1961-1990 гг. по сравнению с 1940-1960 гг. составлял 141,6\%, тогда в 1991-2016 гг. по сравнению с 1961-1990 гг. - 179,1\%. Схожая тенденция отмечается в Китае, Сингапуре и Южной Корее (рисунок 2).

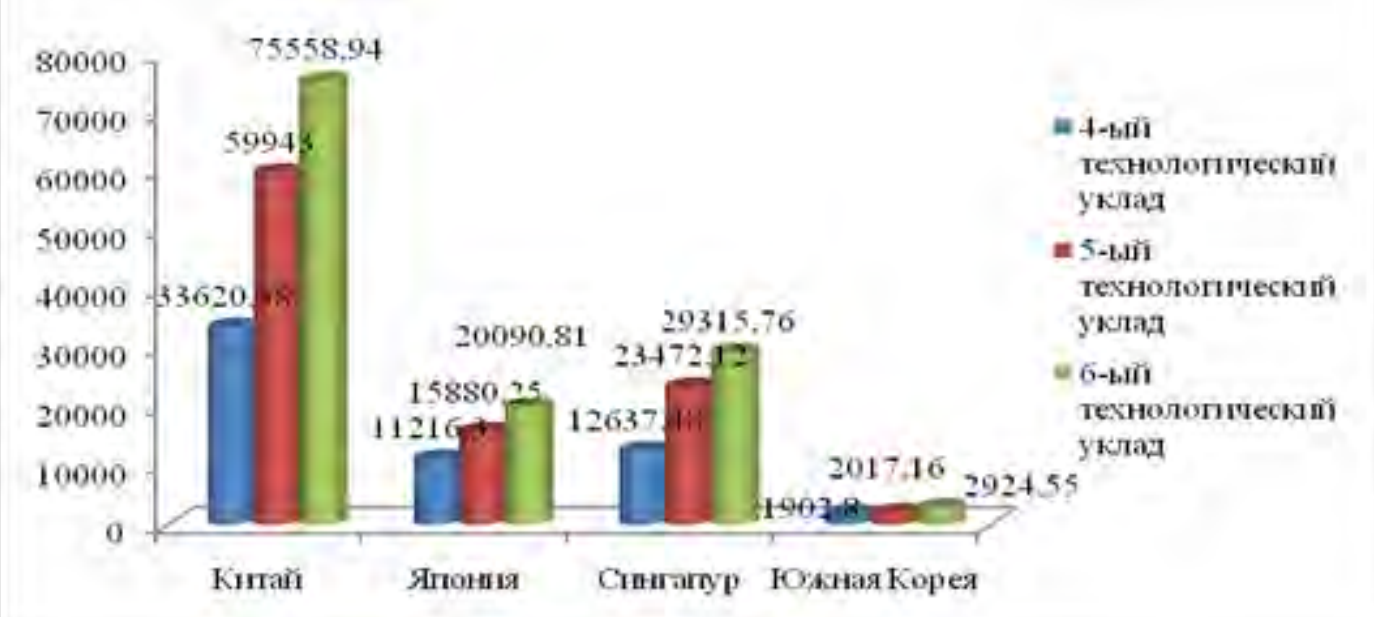

Рисунок 2 - Динамика среднегодовых показателей численности работающих азиатских стран по технологическим укладам, тыс. чел.

Источник: разработка автора на основе [10]

Отличительной чертой Японии является равномерный прирост численности работающих, тогда как рост объемов промышленного производства других азиатских стран 
во многом зависел от прироста численности занятого населения. Так, за 1960-2016 гг. данный показатель в Сингапуре увеличился на 61,7 \%, Южной Корее - 98,4 \%, Китае - 124,7 \% [10].

Качественным показателем роста объемов промышленного производства в исследуемых азиатских странах является производительность труда. Ее динамика по технологическим укладам представлена на рисунке 3.

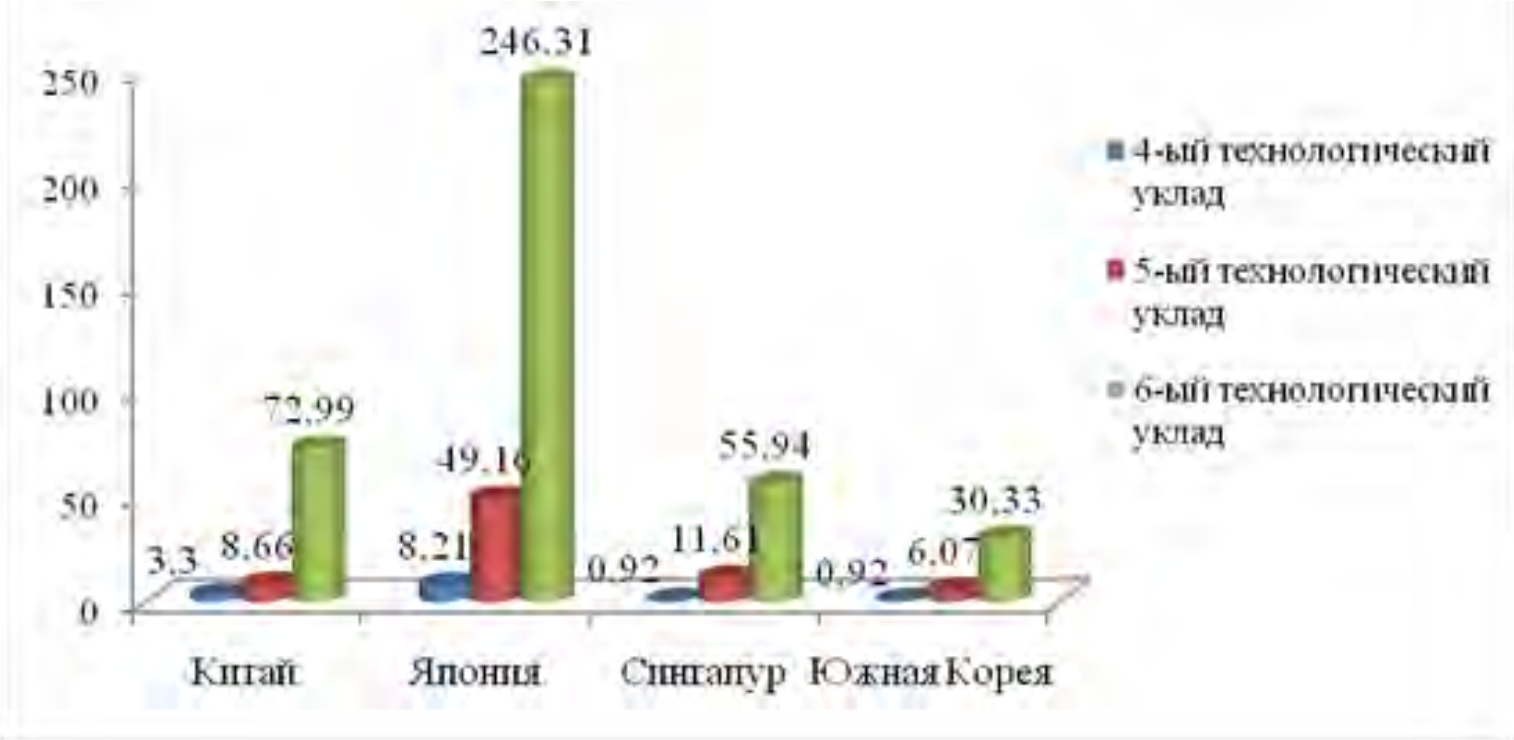

Рисунок 3 - Динамика среднегодовых показателей производительности труда азиатских стран по технологическим укладам, тыс. долл. США на чел.

Источник: разработка автора на основе [10]

Лидером по приумножению производительности труда среди анализируемых стран (Японии, Китая, Южной Кореи и Сингапура) за анализируемый период была Япония. В данном ключе увеличение производительности труда в Японии в период 5-го технологического уклада (1961-1990 гг.) в сравнении с 4-ым технологическим укладом (1940-1960 гг.) составило в 6 раз, 6-ого технологического уклада (1991-2016 гг.) по сравнению с 5-тым в 5 раз. По расчетным данным в Китае рост производительности труда был следующий: в период 5-ого технологического уклада в сравнении с 4-ым - 2,6 раз, 6-ого технологического уклада по сравнению с 5-тым - 8,4 раза. Схожая динамика, пусть недостаточно ярко выраженная, как у Японии и Китая, отмечалась в Южной Корее и Сингапуре.

Это объясняется следующими фактами:

во-первых, различные периоды проведения политики радикальной модернизации промышленного комплекса, которая проводилась в Японии в 1940-50-е гг., в 1950-60-е гг. Южной Корее и Сингапуре и со второй половины 1980-х в Китае.

Япония уже в 1960-х гг. опережала другие развитые страны по темпам экономического роста (среднегодовой показатель за 1961-1970 гг. - 11 \%, для сравнения Китай только в 2000-2010 гг. достиг подобного результата - 10,6 \%). Рост промышленного производства Японии в 1951-1970 гг. в среднем составлял 15,2 \%. Эти результаты промышленной политики Японии определили небывалый рост доходов на душу населения уже в 1980-е гг., который составлял 18 тыс. долл. США (показатель США за аналогичный период был только 15,5 тыс. долл. США). Таким образом, Япония уже в 1961-1990 гг. обладала большими ресурсами и промышленным потенциалом, чем Китай, Сингапур и Южная Корея, что и определило отрыв экономики и промышленного комплекса страны в будущем. 
Представленные данные свидетельствуют о том, что Япония провела комплексную модернизацию национальной экономики и ее промышленного комплекса в 19611990 гг., что и позволило достигнуть наибольших темпов роста производительности труда в период 5-ого технологического уклада. В Китае переходный период пришелся на 1981-2000 гг.

во-вторых, различием механизмов реализации политики модернизации промышленного комплекса. Так, Япония относилась к странам первого эшелона модернизации национальной экономики, в отличие от Китая, и стремилась реализовать американскую модель экономического развития. Так, власти Японии создав в 1981-1983 гг. новейшие монополии (Мицуи, Мицубиси и т. д.), стремились развивать крупные государственные производства с акцентом на формирование долгосрочных торгово-экономических отношений с развитыми странами. Уже в 90-х гг. Япония обладала более совершенной производственной и технической базой, нежели другие азиатские страны.

Мотором развивающегося промышленного комплекса Южной Кореи были опекаемые крупные компании (чеболи). Модернизация проводилась на основе реализации планомерных государственных программ модернизации отраслей. При этом на частный бизнес правительство Южной Кореи оказывала косвенное влияние через косвенное регулирование кредитной сферы, которая вплоть до 90-х гг. жестко контролировалась государством. Данную модель успешно адаптировал под свои социально-экономические условия Китай.

Крупные японские и корейские корпорации с мощными исследовательскими центрами фактически распространили принципы индустриального производства в НИОКР. При этом отсутствие собственной фундаментальной науки в Сингапуре определило низкую эффективность данного инструмента.

Китай в свою очередь при реализации реформ полагался на централизованную администрацию и развитие государственного сектора экономики.

в-третьих, существенные различия в качестве и количестве ресурсов (материальных, природных, трудовых) и геополитическом положении государств.

Азиатско-тихоокеанский регион (АТР) был и остается самым динамичным регионом в мире, где сталкиваются интересы крупнейших экономик (США, Японии и Китая). При этом постоянные территориальные споры Китая в этом регионе обусловливают систематическое возникновение политических проблем с Японией и США, которые стремятся контролировать ситуацию. Кроме политического давления АТР остается достаточно контрастным по уровню жизни населения.

При этом Япония, Сингапур и Южная Корея не обладают значительными природными ресурсами в сравнении с Китаем. Нефть и энергоресурсы эти страны вынуждены импортировать, а экспорт составляют уже готовые товары. Китай, в свою очередь, является лидером по запасам многих природных ископаемых таких как: уголь, железная руда, нефть, цинк и т. д. Это позволяет Китаю чувствовать себя более уверенно в ситуации обострения внешнеэкономических и политических проблем.

Культурные особенности стран Азии также четко выражены: у китайцев - это коллективизм и «послушание», у японцев - бережливость, корейцев - строгая «иерархичность» подчинения. Общая черта населения азиатских стран - это трудолюбие.

Все вышеперечисленные факторы влияния определяют общую тенденцию развития всего азиатского региона.

Проведенное исследование опыта ряда азиатских стран в контексте результатов модернизации национальной экономики и ее промышленного комплекса в период 4,5 и 6-го технологических укладов позволил выявить общие черты экономического трансформирования: 
- опора на рост аграрного производства на начальном этапе и социально-экономические преобразования в сельской местности, позволившие создать необходимый «производственный запас» для проведения индустриализации;

- первоначальные капиталовложения в модернизацию осуществлялись в ведущие отрасли, как правило, связанные с добычей и переработкой природных ресурсов (металлургическая, нефтехимическая и т. д.);

- на втором этапе развивались инновационные производства: машино- и приборостроение, электроника, биотехнологии и т. д.;

- форсированный рост производительности труда при невысоких заработных платах;

- практически все азиатские страны характеризуются «культурой послушания» и «иерархичного подчинения», которая побуждает распространение пассивной, некритичной ориентации развития;

- рост расходов на финансирование научных и технических исследований, основными ценностями становятся знания.

Все это говорит о многоэтапности и продолжительности перехода развивающихся государств к развитым, который может охватывать более 50-ти лет. При этом ускоренные темпы реализации реформ и модернизации национальных экономик обусловлены глобализацией, в том числе - новым информационным технологиям, которые позволили быстро осуществлять обмен опытом между странами.

Перспективным направлением для воспроизводства экономики Китая являлось обеспечение существенного роста производительности труда, создание новых рабочих мест и оптимизация расходов на производство («бережливое производство»).

Наглядно видна схожая динамика темпа роста производительности труда и заработной платы в Китае за исследуемый период, однако, если представить соотношение этих показателей в период быстрой модернизации и уже выхода промышленного комплекса Китая практически на 100 \% мощность (2001-2016 гг.) можем отметить превышение темпов прироста производительности труда на 17,3 \% (см. рисунок 4).

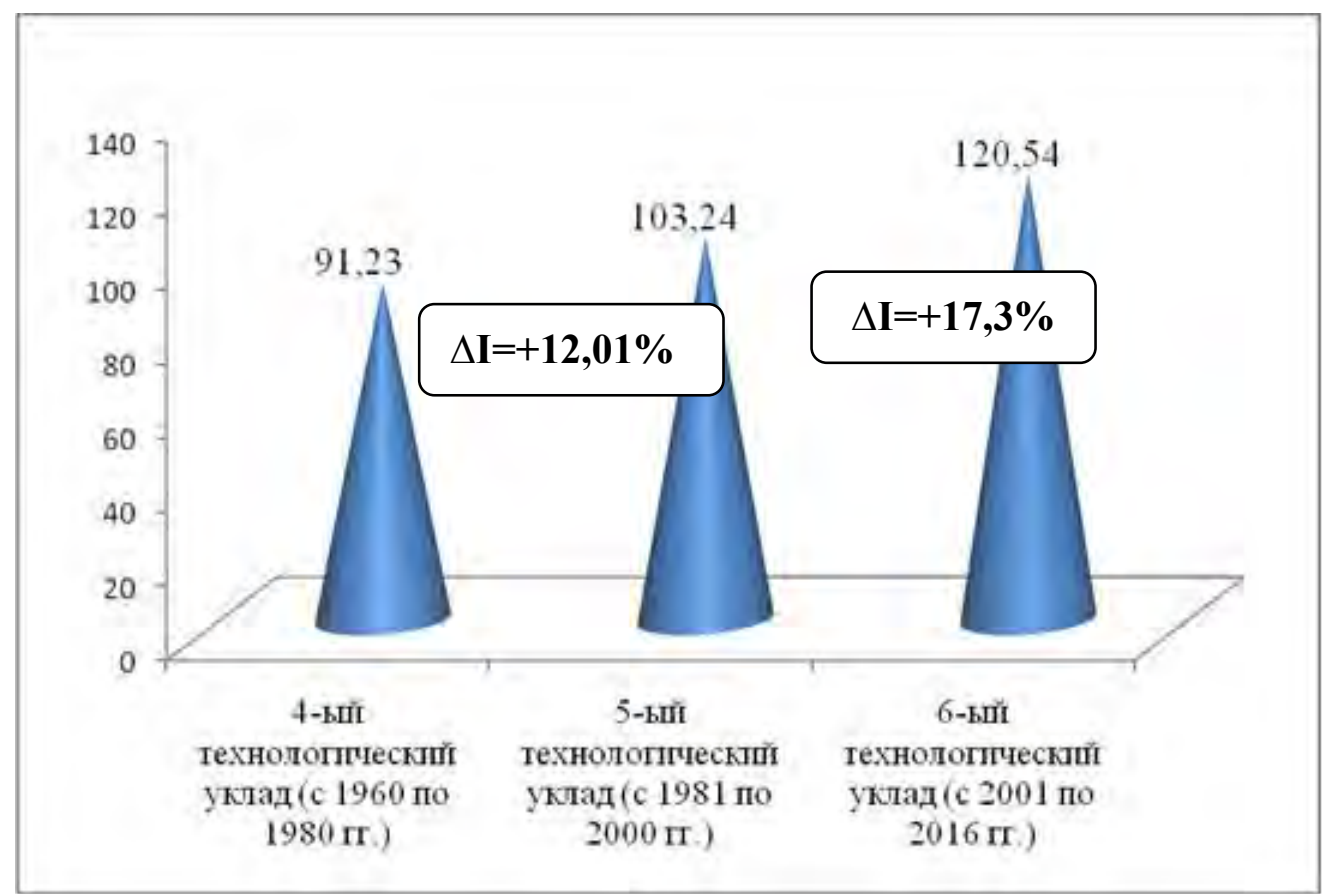

Рисунок 4 - Динамика соотношения темпа роста производительности труда и оплаты труда в Китае за 1960-2016 гг., \%

Источник: разработка автора на основе [10] 
Практика последних лет доказывает, что роль высококвалифицированных специалистов по экономике и организации труда на предприятиях стала возрастать. В связи с чем, в Китае стали активно применятся новые формы оплаты труда таких специалистов с целью оптимизации производственных процессов путем использования современного научно-методического арсенала. Структурные преобразования в системе трудовых ресурсов определили мотивацию работников к саморазвитию, а эффективное управление и модернизация позволили сократить неэффективных сотрудников. Все это позволило Китаю снизить темпы роста оплаты труда над производительностью.

С целью сравнения динамики соотношения темпов роста реальной оплаты труда и производительности труда в Республике Беларусь за период ее независимости (19952016 гг.) рассмотрим данные таблицы 3.

Таблица 3 - Динамика соотношения темпа роста оплаты труда и производительности труда в Республике Беларусь за 1995-2016 гг., \%

\begin{tabular}{|c|c|c|c|c|c|c|c|c|}
\hline Годы & ВВП & TP & ПТ & ЗП & ІПТ & ІЗП & ІПТ/ІЗП & $\begin{array}{c}\text { средний } 5 \text { лет } \\
\text { IПТ/ІЗП сотн- } \\
\text { шения темпа роста }\end{array}$ \\
\hline 1995 & 14,4 & 4410 & 3,27 & 30 & 118,3 & 105,3 & 112,3 & \multirow{5}{*}{92,85} \\
\hline 1996 & 15 & 4365 & 3,44 & 33 & 105,2 & 110,0 & 95,63 & \\
\hline 1997 & 14,6 & 4370 & 3,34 & 39 & 97,2 & 118,2 & 82,23 & \\
\hline 1998 & 15,8 & 4417 & 3,58 & 41 & 107,1 & 105,1 & 101,9 & \\
\hline 1999 & 12,6 & 4442 & 2,84 & 45 & 79,3 & 109,8 & 72,22 & \\
\hline 2000 & 10,4 & 4444 & 2,34 & 67,2 & 120,2 & 127,4 & 94,34 & \multirow{5}{*}{97,68} \\
\hline 2001 & 12,4 & 4442 & 2,79 & 88,5 & 119,3 & 131,7 & 90,58 & \\
\hline 2002 & 14,6 & 4387 & 3,33 & 105,7 & 119,2 & 119,4 & 99,83 & \\
\hline 2003 & 17,8 & 4347 & 4,09 & 122,2 & 123 & 115,6 & 106,4 & \\
\hline 2004 & 22,7 & 4326 & 5,25 & 160,9 & 128,1 & 131,7 & 97,26 & \\
\hline 2005 & 30,2 & 4414 & 6,84 & 215,3 & 130,4 & 133,8 & 97,45 & \multirow{5}{*}{98,5} \\
\hline 2006 & 37 & 4470 & 8,28 & 271,5 & 121 & 126,1 & 95,95 & \\
\hline 2007 & 45,3 & 4518 & 10,03 & 323,4 & 121,1 & 119,1 & 101,67 & \\
\hline 2008 & 60,8 & 4610 & 13,19 & 406,4 & 131,5 & 125,7 & 104,61 & \\
\hline 2009 & 49,2 & 4644 & 10,59 & 351,4 & 80,3 & 86,5 & 92,83 & \\
\hline 2010 & 54,7 & 4703 & 11,63 & 408,7 & 109,8 & 116,3 & 94,41 & \multirow{5}{*}{99,44} \\
\hline 2011 & 57,7 & 4691 & 12,3 & 381,9 & 105,8 & 93,4 & 113,27 & \\
\hline 2012 & 58,2 & 4612 & 12,62 & 440,9 & 102,6 & 115,4 & 88.9 & \\
\hline 2013 & 69,2 & 4578 & 15,12 & 570 & 119,8 & 129,3 & 92.65 & \\
\hline 2014 & 77,2 & 4550 & 16,97 & 592 & 112,2 & 103,9 & 107.98 & \\
\hline 2015 & 62 & 4496 & 13,79 & 421,6 & 81,3 & 71,2 & 114.18 & \multirow{2}{*}{97,49} \\
\hline 2016 & 48,1 & 4406 & 10,92 & 413,2 & 79,2 & 98 & 80.81 & \\
\hline
\end{tabular}

Источник: разработка автора на основе [11] 


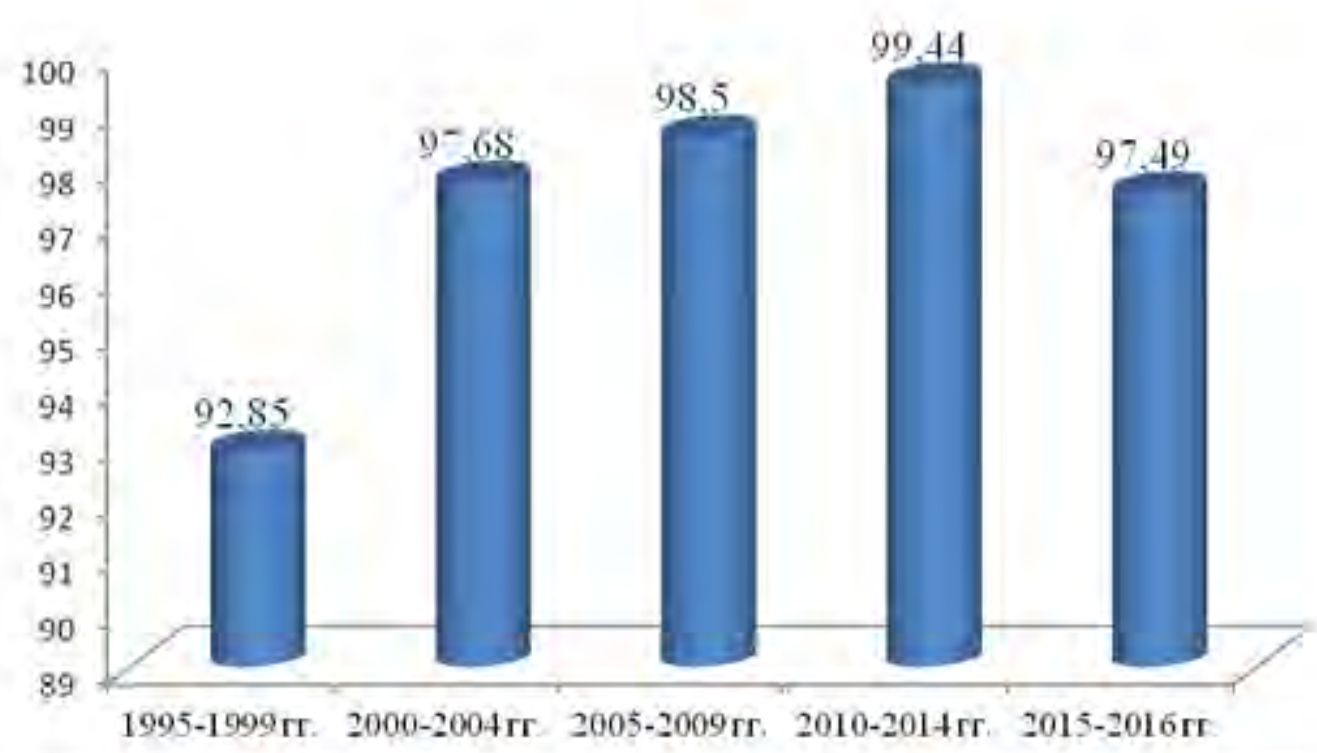

Рисунок 5 - Динамика соотношения темпа роста производительности труда и оплаты труда в Беларусь за 1995-2016 гг., \%

Источник: разработка автора на основе [11]

Данные таблицы свидетельствуют о цикличности изменения темпа роста оплаты труда и производительности труда в Республике Беларусь (микроцикл - 2-3 года). Вариация изменений при переходе от роста к снижению достаточно широкая $-9-25 \%$. Это свидетельствует о нестабильности экономики страны и необходимости реформирования промышленной отрасли. В данной связи опыт Китая, который показывает стабильные результаты, является перспективным к адаптации в белорусских условиях.

Высокий уровень конкурентоспособности промышленного комплекса Китая в условиях глобализации и развитии экономики, основанной на знаниях и инновациях, направлен, в первую очередь, на обеспечение национальной безопасности. При этом в ходе проводимых реформ, отдельные направления промышленной политики Китая дорабатывались с учетом изменения общемировых тенденций. Так, в 2006 г. китайские власти взяли курс на инновационное развитие страны («Основные положения государственной средне- и долгосрочной программы науки и техники на 2006-2020 гг.).

В отчете «Обзор модернизации в мире и Китае» (1998 г.), преподаватель Хэ Чуэнки выдвинул теорию вторичной модернизации, обеспечившей переход Китая от индустриального общества к теории знаний. По его мнению, если первым этапом модернизации промышленного комплекса (основная фаза) в Китае была так называемая «классическая модернизация», которая включает индустриализацию, урбанизацию, демократизацию и рациональный подходы, то второму этапу (вторичная фаза) характерна «неомодернизация», включающая в себя понятие научных знаний, информации, глобализации и охрана окружающей среды. Гармоничное развитие обеих фаз означает успех «интегрированной модернизации» [7, с. 18].

Подчеркивание исторической последовательности обеих фаз для Китая позволяет выделить метод комбинации основных и вторичных задач модернизации промышленного комплекса. Таким образом, выбор общей стратегии модернизации промышленного комплекса Китая основывался, главным образом, на выполнении трех главных задач:

1) сохранения власти в руках правящей партии, сосредотачивая людей на достижении целей экономического роста и повышения уровня благосостояния населения; 
2) создания повсеместной поддержки государственного аппарата, реализующего экономические реформы;

3) рост политического значения и конкурентоспособности страны, чтобы гарантировать выходы экспортных промышленных производств на международные рынки [8, с. 26].

Многие авторы сходятся во мнении, что власти Китая реализуют социалистическую модернизации промышленного комплекса, и это означает, что высшее китайское руководство определило экономический домен как основание для социалистической модернизации, реализации политических реформ, которые осознаны и постепенно реализуются в китайском обществе.

Согласно программе развития приоритетных областей Китая к 2050 г. главным инициативам модернизации промышленного комплекса будут являться следующие [9, с. 92]:

- экологическое производство из высококачественного сырья.

Важность этого направления уже давно осознана мировым сообществом. Одной из научно-технических задач Китая, требующих внимательного рассмотрения, является формирование современного инновационно-промышленного комплекса, позволяющего производить высококачественную продукцию с минимальным экологическим ущербом.

- технология более эффективной переработки и использования ресурсов.

Губительное воздействие на окружающую среду обрабатывающей промышленности, главным образом, относящийся к перерабатывающим отраслям промышленности из-за их массового потребления естественных ресурсов и энергии выходит на первый уровень проблематики модернизации промышленного комплекса Китая. Будущие научные исследования должны быть сконцентрированы на запуске чистых производств и новых технологий, способных к эффективному управлению источниками загрязнения и эффективному использованию ресурсов.

- «повсеместное информационное производство».

Производство систем со зрелостью таких технологий как промышленная беспроводная сеть, сенсорная сеть, радиочастотная идентификация (RFID) и микроэлектронная механическая система (MEMS) повышает возможности человека к управлению автоматизированными процессами производства и позволяет эффективно использовать информацию. Разработка новых систем автоматизации и технологии промышленного производства Китая позволит преобразовать существующее «недостаточное обеспечение» технологического оборудования и производственного процесса.

\section{ВЫВОДЫ}

В условиях «четвертой промышленной революции» экономическое развитие любой страны определяется прогрессом ее индустриально-промышленного комплекса. В связи с этим инновационная политика в промышленности, нацеленная на модернизацию (инновационное обновление) как самого промышленного комплекса, так и национальной экономики в целом, выступает важным фактором глобальной конкурентоспособности современной технологически развитой державы.

Изучение специфики инновационного обновления национальной экономики ряда успешных азиатских стран (Японии, Южной Кореи, Сингапур, Китай) позволило выявить их общие черты, что позволяет вести речь об «азиатской модели модернизации экономики». Основой этой модели является то, что «локомотивом», основным «драйвером» модернизации экономики в целом выступает промышленность, которая поставляет прогрессивные орудия труда во все прочие сферы народного хозяйства и тем самым повышает общественную производительность труда. 
Осуществленный нами анализ инновационного развития перечисленных выше азиатских стран однозначно доказал, что ускоренный рост производительности труда за счет внедрения новой техники и технологий во все отрасли и сферы жизнедеятельности общества - это главная цель и характерный признак модернизации, инновационного обновления национальной экономики. При этом было показано, что смена технологических укладов как процесс модернизации национальной экономики сопровождается существенным (кратным) ростом производительности труда за счет повсеместного распространения новой высокопроизводительной техники, являющейся продукцией индустриально-промышленного комплекса.

Исходя из этого мы дано новое определение модернизации национальной экономики как комплекса технико-технологических и организационно-управленческих мероприятий, обеспечивающих ускоренное повышение производительности труда за счет массированного внедрения в национальную экономику факторов, относящихся к высшим технологическим укладам.

При этом нами выявлены следующие ключевые особенностями «азиатской модели модернизации»:

1) ведущая роль государства в процессе создания отечественным предприятиям предельно благоприятных условий хозяйствования как в национальной экономике для инновационного обновления (стимулирующая кредитно-денежная, бюджетно-налоговая, научно-техническая, образовательная и т. д. политика), так и на международной арене (всемерная экономическая и политическая поддержка государством собственных ТНК);

2) ставка на привлечение современных зарубежных технологий с последующей их адаптацией и копированием - на первом этапе, а затем массированные инвестиции в научно-исследовательскую и инновационную деятельность с целью разработки, внедрения и экспорта собственных передовых технологий - на втором этапе модернизации;

3) опора на традиционные сферы экономики с целью создания так называемого «производственного запаса» - накопления ресурсов для осуществления в дальнейшем модернизации путем ускоренного развития индустриально-промышленного комплекса и осуществления новой индустриализации;

4) создание (развитие) сырьевой базы для осуществления технико-технологической модернизации и новой индустриализации за счет масштабных инвестиций на первом ее этапе в сырьевые и «околосырьевые» отрасли национальной экономики;

5) макроэкономическое стимулирование процесса модернизации инновационного обновления экономики на основе фундаментального принципа «опережающий рост производительности труда по сравнению с ростом заработной платы», то есть форсированный рост производительности труда при сдерживании роста заработной платы;

6) учет и использование культурных особенностей народов азиатских стран (коллективизм, послушание, иерархичность подчинения и др.), что предопределило ведущую роль государственных институтов в осуществлении модернизации и экономических реформ.

На наш взгляд, многие элементы «азиатской модели модернизации», позволившей Китаю в считанные годы превратиться из региональной аграрно-индустриальной страны в одного из мировых лидеров технико-технологического прогресса, могут быть использованы и в Республике Беларусь.

\section{СПИСОК ИСПОЛЬЗОВАННЫХ ИСТОЧНИКОВ}

1. Байнев, В. Ф. Индустриальная революция в «постиндустриальной» экономике / В. Ф. Байнев // Беларуская думка. - Минск, 2017. - № 5. - С. 50-55. 
2. Байнев, В. Ф. Четвертая промышленная революция как технико-технологический и политико-экономический феномен / В. Ф. Байнев, Чжан Бинь // Новая экономика. Минск, 2017. - № 1 (69). - С. 4-10.

3. Новые ресурсы экономической модернизации: [монография] / С. Ю. Солодовников, Л. П. Васюченок, Ю. В. Мелешко и А. Н. Тур ; под ред. С. Ю. Солодовников. Минск : БНТУ, 2016. - 324 с.

4. Маркс, К. Экономические рукописи 1857-1859 годов / К. Маркс, Ф. Энгельс. Соч. 2-е изд. - Т. 46. - Ч. І. - 560 с.

5. Ленин В. И. Великий почин / В. И. Ленин // Полное собрание сочинени; 5-е изд. Т. 39. - М.: Изд-во политической литератрур, 1970. - С. 21.

6. Выступление Си Цзиньпина на XIX Всекитайском съезде КПК [Электронный pecypc]. - Режим доступа: http://cpc.people.com.cn/19th/n1/2017/1018/c41430529594508.html - Дата доступа: 05.01.2018.

7. China Modernization Report Outlook 2001-2010 (Russian edition). Moscow: «Ves’ mir» press, 2011.

8. Golubovich, A., Fundobnyi, S., Orlova, A. Experience of modernization in China / A. Golubovich, S. Fundobnyi, A. Orlova // Arbat capital, 2010.

9. Science \& Technology in China: A Roadmap to 2050. [Electronic resource]. - Mode of access: http://library.aceondo.net/ebooks/HISTORY/Science_\&_Technology_in_China A_Roadmap_to_2050_Strategic_General_Report_of_the_20121130215622420.pdf. - Date of access : 23.11.2017.

10. World Bank [Electronic resource]. - Mode of access: http://www.worldbank.org. Date of access : 23.11.2017.

11. UNECE. 2017 [Electronic resource]. - Mode of access: w3.unece.org. - Date of access : 19.01.2018.

\section{REFERENCES}

1. Bajnev, V. F. Industrial'naya revolyuciya v «postindustrial'noj» ehkonomi-ke / V. F. Bajnev // Belaruskaya dumka. - Minsk, 2017. - № 5. - S. 50-55.

2. Bajnev, V. F. CHetvertaya promyshlennaya revolyuciya kak tekhniko-tekhnologicheskij i politiko-ehkonomicheskij fenomen / V. F. Bajnev, CHzhan Bin' // Novaya ehkonomika. - Minsk, 2017. - № 1 (69). - S. 4-10.

3. Novye resursy ehkonomicheskoj modernizacii: [monografiya] / S. Yu. Solo-dovnikov, L. P. Vasyuchenok, Yu. V. Meleshko i A. N. Tur ; pod red. S. Yu. Solodovni-kov. Minsk : BNTU, 2016. - 324 s.

4. Marks, K. EHkonomicheskie rukopisi 1857-1859 godov/ K. Marks, F. EHn-gel's. Soch. 2-e izd. - T. 46. - CH. I. - $560 \mathrm{~s}$.

5. Lenin V. I. Velikij pochin / V. I. Lenin // Polnoe sobranie sochineni; 5-e izd. - T. 39. M.: Izd-vo politicheskoj literatrur, 1970. - S. 21.

6. Vystuplenie Si Czin'pina na XIX Vsekitajskom s"ezde KPK [EHlektron-nyj resurs]. Rezhim dostupa: http://cpc.people.com.cn/19th/n1/2017/1018/c414305-29594508.html - Data dostupa: 05.01.2018.

7. China Modernization Report Outlook 2001-2010 (Russian edition). Moscow: «Ves’ mir» press, 2011.

8. Golubovich A., Fundobnyi S., A. Orlova A. Experience of modernization in China. Arbat capital, 2010.

9. Science \& Technology in China: A Roadmap to 2050. [Electronic resource]. - 2017. Mode of access: http://library.aceondo.net/ebooks/HISTORY/Science_\&_Technology_ 
in_China_A_Roadmap_to_2050_Strategic_General_Report_of_the_20121130215622420.pdf. Date of access: 23.11.2017.

10. World Bank [Electronic resource]. - 2017. - Mode of access: http://www.worldbank.org. - Date of access: 23.11.2017.

11. UNECE [Electronic resource]. - 2017. - Mode of access: w3.unece.org. - Date of access : 19.01.2018.

Статья поступила в редакциюю 13 марта 2018 года. 